\title{
Polycythaemia rubra vera and hairy cell leukaemia in the same patient: studies on the spleen
}

\author{
GJ MUFTI, TJ HAMBLIN, FK STEVENSON,${ }^{*}$ M FITCHETT $†$
}

From the Department of Haematology, Royal Victoria Hospital, Bournemouth, the * Regional Immunology Unit, Tenovus Research Laboratory, General Hospital, Southampton and the †Regional Cytogenetics.Unit, General Hospital, Salisbury

SUMMARY The first association of polycythaemia rubra vera (PRV) and hairy cell leukaemia $(\mathrm{HCL})$ is reported. The secretion by spleen cells in short term culture of $\operatorname{IgG} \lambda$ to the exclusion $\kappa$ demonstrated that despite aberrant surface marker studies the HCL was a monoclonal tumour of $B$ cells. Chromosomal studies on splenic cells were not able to demonstrate the common clonal origin of the two tumours.

The simultaneous or sequential development of lymphoproliferative and myeloproliferative disorders in the same patient is being reported with increasing frequency.! Polycythaemia rubra vera (PRV) has been reported in combination with chronic lymphocytic leukaemia, ${ }^{2}$ non-Hodgkin's lymphoma ${ }^{3}$ and multiple myeloma. ${ }^{45}$ We describe a patient with PRV who subsequently developed hairy cell leukaemia (HCL), a phenomenon which, to our knowledge, has not been reported previously.

\section{Case report}

A 53-year-old man presented in October 1978 with a red face, a tender mass in the left hypochondrium, blue toes, headaches and transient attacks of numbness down his right side. He had had a pyeloplasty of his left kidney for a renal calculus eight years previously and a duodenal ulcer treated medically 15 years previously.

On examination he was plethoric and his liver was palpable $3 \mathrm{~cm}$ and spleen $6 \mathrm{~cm}$ below the costal margins. Cardiovascular respiratory and central nervous systems were normal. Investigations showed Hb $23.3 \mathrm{~g} / \mathrm{dl}, \mathrm{RBC} 9.52 \times 10^{12} / 1$, PCV $76 \%$, MCV 75 fl, WBC $11.1 \times 10^{9} / 1$ (neutrophils $84 \%$, lymphocytes $12 \%$, monocytes $3 \%$, eosinophils $1 \%$ ), platelet count $295 \times 10^{4} / 1$; neutrophil alkaline phosphate (NAP) score 244 (normal control 38). Bone marrow showed marked hypercellularity of all cell lines and depleted iron stores. Serum urate was $0.44 \mathrm{mmol} / \mathrm{l}$ (NR 0.12-

Accepted for publication 24 May 1982
$0 \cdot 38$ ), creatinine $129 \mu \mathrm{mol} / \mathrm{l}$. Liver function tests, chest $x$-ray, electrocardiogram and intravenous pyelogram were normal.

A diagnosis of polycythaemia rubra vera was made and he was then treated with ${ }^{32} \mathrm{P}$ and allopurinol. After this treatment his symptoms improved, his spleen was no longer palpable and the $\mathrm{Hb}$ remained within the normal range. His further progress is shown in Fig. 1. His subsequent treatment included bulsulphan, hydroxyurea and further ${ }^{32} \mathrm{P}$. Despite control of his haemoglobin level his spleen began to enlarge and by June 1981 was palpable $11 \mathrm{~cm}$ below the costal margin. He also had a persistent neutropenia $\left(0.6 \times 10^{9} / \mathrm{l}\right)$ and thrombocytopenia $\left(40 \times 10^{9} / 1\right)$ that did not improve on the withdrawal of cytotoxic drugs. A peripheral blood film at this time showed that $10 \%$ of the lymphocytes were recognisably "hairy", and $50 \%$ of the patient's buffy coat mononuclear cells contained tartrate-resistant acid phosphatase. Further investigations showed normal serum immunoglobulins and no detectable free light chains in the urine. Abdominal $x$-ray and ${ }^{99} \mathrm{Tc}$ spleen scan confirmed massive spenomegaly. Bone marrow aspirations performed on two occasions were aparticulate and hypocellular with only a few myeloid and erythroid precursors seen. Fifty per cent of the mononuclear cells were hairy cells and contained tartrate-resistant acid phosphatase. Bone marrow trephine biopsy was hypercellular and infiltrated with mononuclear cells. Myelopoiesis was depressed, megakaryocytes were normal and reticulin was increased. Ultrastructurally some of the bone marrow mononuclear cells showed prominent long cytoplasmic projections and pinocytic vacuoles (Fig. 2). 


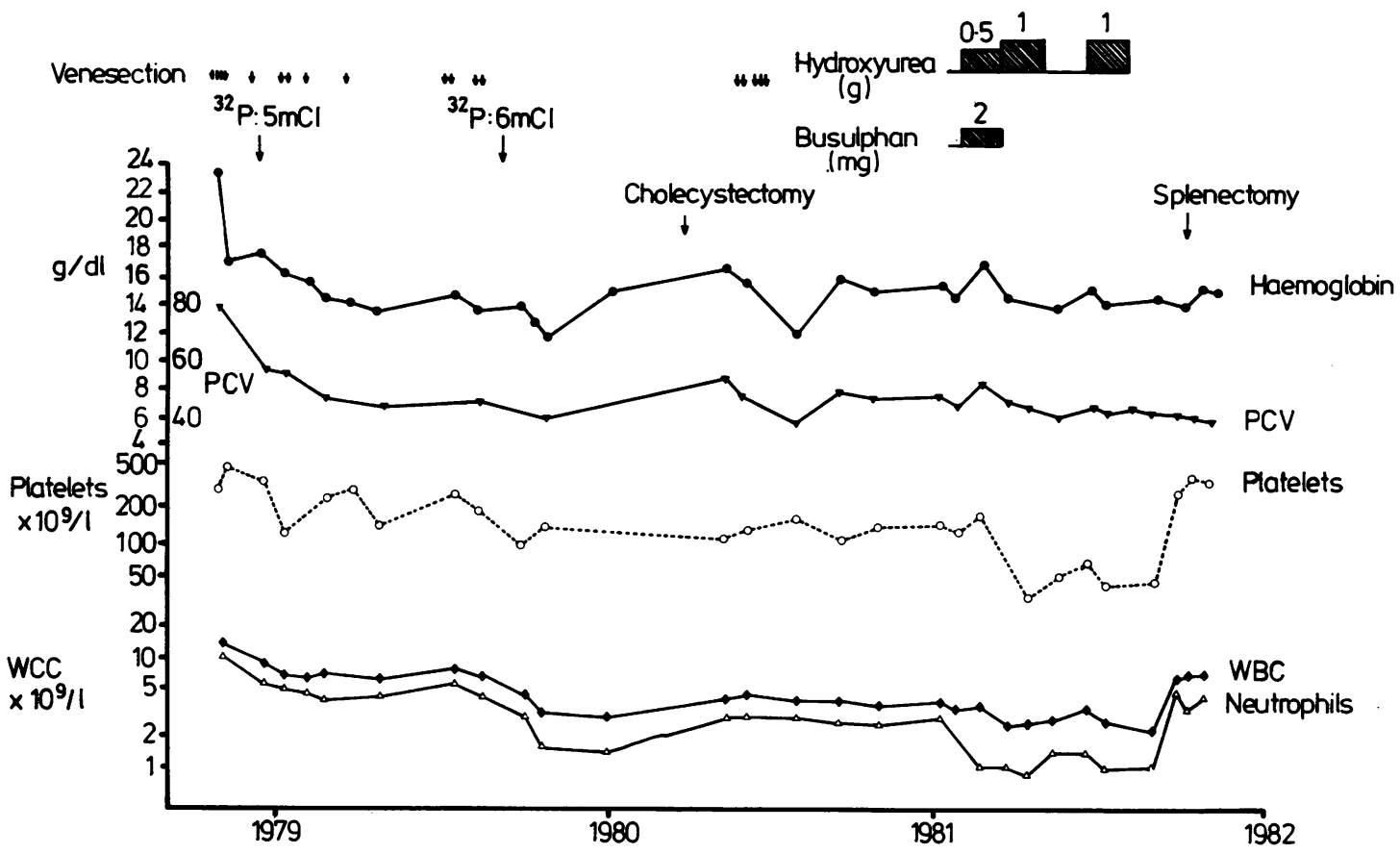

Fig. 1 Summary of clinical progress.

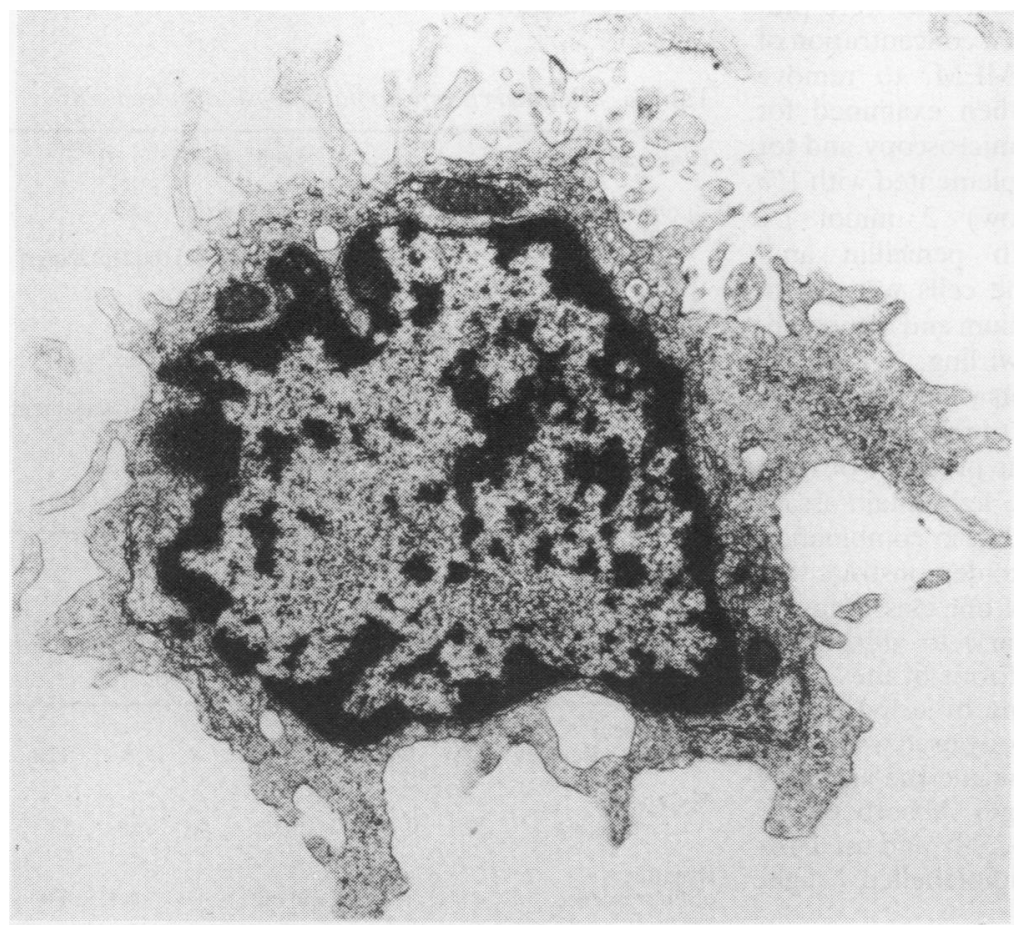

Fig. 2 Hairy cell from bone marrow $\times 12000$. 
Cell marker studies were unsatisfactory because of the paucity of hairy cells in both the peripheral blood and bone marrow aspirates and the admixture of normal lymphoid cells. Banded chromosomal analysis performed on bone marrow cells showed a normal 46 XY karyotype.

A diagnosis of hairy cell leukaemia was made and, in view of his worsening neutropenia and thrombocytopenia, splenectomy was performed in August 1981. The spleen weighed $2.5 \mathrm{~kg}$. Histological examination of the spleen showed diffuse infiltration by mononuclear cells, many of which showed lobulated and irregular nuclei. Imprint preparations made from fresh spleen showed large numbers of hairy cells containing tartrate resistant acid phosphatase. The patient's post operative course was uneventful and he is currently well with $\mathrm{Hb} 13.9 \mathrm{~g} / \mathrm{dl}$, WBC $7.6 \times 10^{9} / 1$ (neutrophils $76 \%$, lymphocytes $18 \%$, monocytes $4 \%$, eosinophils $2 \%$ ) and platelets $379 \times 109 / 1$.

\section{SPLEEN STUDIES}

\section{Methods}

For studies of lymphocyte markers and in vitro immunoglobulin production, part of the spleen was chopped and left overnight in Eagle's minimum essential medium (MEM) with $20 \%$ fetal calf serum (FCS) at $4^{\circ} \mathrm{C}$. The following day it was teased and washed and the cell suspension separated on a FicollHypaque gradient. Splenic lymphoid cells were preincubated at $37^{\circ} \mathrm{C}$ for two hours at a concentration of $2 \times 10^{7} / \mathrm{ml}$ in supplemented MEM, to remove cytophilic Ig. An aliquot was then examined for surface markers by fluorescence microscopy and for the remainder the MEM was supplemented with $1 \%$ non-essential amino acids (Flow) $2 \mathrm{mmol}$ Lglutamine, $100 \mathrm{IU} / \mathrm{ml}$ of both penicillin and streptomycin, and $10 \%$ FCS. The cells were then resuspended in supplemented medium and incubated at $2 \times 10^{7} / \mathrm{ml}$ at $37^{\circ} \mathrm{C}$ with gentle swirling.

To assess Ig production, aliquots were removed at intervals and after centrifugation to remove cells the supernatants were analysed for the presence of IgM, IgG, $\kappa$ chains and $\lambda$ chains. ${ }^{6}$ The light chain assays detect both free light chain and that in combination with heavy chain, and serve only to demonstrate that Ig production is predominantly of one class. Having established this, it was necessary to distinguish between the different molecular forms of the $\lambda$ light chain produced and this was done by using a RIA specific for free $\lambda$ chain. The antibody used was raised in sheep by injecting $\lambda$ light chains and the antibody was absorbed with whole human IgG. Absorbed antibody was coupled to Sephadex G-25 SF and used in a solid phase RIA system with radiolabelled $\lambda$ light chains as antigen.

\section{RESULTS}

\section{Chromosome studies}

The direct preparation yielded only four metaphases suitable for analysis, all of which showed a normal karyotype. The results of analysis of preparations of cells stimulated by B cell mitogens are shown in Table 1. They show a number of random abnormalities in 8 of 63 cells examined. No evidence of clonal proliferation is seen.

\section{Lymphocyte markers}

The results of the lymphocyte marker studies are shown in Table 2. T 28 is monoclonal antibody raised against mature $\mathrm{T}$. cells now designated UCH 1 . Both light chain types could be detected on the cell surface of different $B$ cells and there was, therefore, no evidence of a clonal proliferation of B cells.

\section{Immunoglobulin synthesis}

The results of analysis of culture supernatants obtained over an eight-hour incubation period are shown in Table 3. Although surface fluorescence was seen with both anti- $\kappa$ and $\lambda$ antibodies, the monotypic nature of the cells can be seen in the culture products where only one light chain type was found in significant amounts. It appears that the $\lambda$ reactivity is made up of two components, one being free $\lambda$ chain and the other IgG $\lambda$. The amount of IgM produced was insignificant.

Table 1 Banded chromosomal analysis of spleen cells

\begin{tabular}{lc}
\hline Direct culture: & 4 cells, 46 XY \\
Lipopolysaccharide 5 day culture: & 30 cells, 46 XY \\
Stimulated cells & 1 cell 5p- \\
& 1 cell t (6:22) (6q22p:22q6p) \\
Pokeweed 5 day culture: & 20 cells, 46 XY \\
Stimulated cells & 1 cell del (2) (ql?) \\
& 1 cell t (11:16) (?q13:p13) \\
& 1 cell 47 XY + 4 \\
& 1 cell multiple rearrangements \\
Pokeweed 7 day culture: & 13 cells, 46 XY \\
Stimulated cells & 1 cell peri inv (10) \\
& 1 cell t (9:15) (p13:q11) \\
\hline
\end{tabular}

75 cells examined. 67 cells showed no abnormalities.

Table 2 Surface immunofluorescence of splenic lymphoid cells

\begin{tabular}{llllllllll}
\hline $\begin{array}{l}\text { Fluorescent } \\
\text { antibody specificity }\end{array}$ & IgM & IgD & IgG & IgA & $\kappa$ & $\lambda$ & T28 \\
$\begin{array}{l}\% \text { Cells } \\
\text { reacting }\end{array}$ & 52 & 0 & 58 & 0 & 46 & 60 & 17 \\
$\begin{array}{l}\text { Brightness } \\
\text { of fluorescence }\end{array}$ & ++ & - & +++ & & ++ & ++ & ++ \\
\hline
\end{tabular}


Table 3 Ig production (ng/ml) by splenic cells: amount present in culture supernatant at specified times

\begin{tabular}{llllll}
\hline Time $(h)$ & $\lg M$ & $\operatorname{Ig} G$ & $\lambda$ combined & $\lambda$ free & $\kappa$ combined \\
\hline 0 & 0 & 93 & $32 \cdot 5$ & $8 \cdot 0$ & $6 \cdot 1$ \\
1 & 0 & 173 & 106 & 110 & $8 \cdot 6$ \\
2 & 0 & 197 & 175 & 160 & $13 \cdot 0$ \\
3 & $4 \cdot 8$ & 240 & 300 & 240 & $14 \cdot 8$ \\
8 & $6 \cdot 8$ & 380 & 650 & 400 & $19 \cdot 0$ \\
\hline
\end{tabular}

\section{Discussion}

In this case report we document a unique case of PRV which subsequently developed hairy cell leukaemia. The diagnosis of PRV was never in doubt with a very high haemoglobin and red cell count, neutrophil leucocytosis, raised NAP score, splenomegaly and evidence of peripheral and cerebral ischaemia. The responses to venesection and ${ }^{32} \mathrm{P}$ were as expected. However, when a second course of $32 \mathrm{P}$ became necessary because of a rising $\mathrm{Hb}$ the resulting neutropenia was never alleviated and the spleen continued to enlarge. Thirty months after his initial presentation a diagnosis of hairy cell leukaemia was made. The monoclonal nature of the hairy cells could not easily be- established since surface immunofluorescence demonstrated the presence of both light chain types. One explanation for this might have been an admixture of normal cells but since the total numbers of $T$ cells $\boldsymbol{\kappa}$-bearing cells and $\boldsymbol{\lambda}$-bearing cells exceeded $100 \%$, some cells must have borne dual markers. Hairy cells are known to possess avid receptors for both $\mathrm{Fc} \mu$ and $\mathrm{Fc} \gamma$ and thus it is likely that the marker studies were confused by exogenous surface immunoglobulin. The production of only one type of light chain by the splenic cells in culture strongly suggests a $B$ cell neoplasm and the finding of free light chain is consistent with other studies in B cell tumours ${ }^{7}$ although the biosynthetic methods used by these investigators did not demonstrate an export of IgG. Evidently the disease is heterogeneous. The finding of IgG in the supernatant at the zero time point is unusual and has not been found by us in a large series of CLL cells (unpublished observations). It may be the result of resuspending the neoplastic cells in medium. The microvilli of hairy cells may be particularly fragile and form vesicles which carry $\mathrm{IgG}$.

Chromosome studies were undertaken in the hope that they would demonstrate a common clonal origin for spontaneously dividing (and presumably PRV) cells and those stimulated to divide by $B$ cell mitogens. However, only random abnormalities of the type induced by previous radiotherapy were demonstrated.

Myeloproliferative diseases frequently terminate as acute leukaemias and in PRV this is more likely after treatment with ${ }^{32} \mathrm{P} .{ }^{\times}$Chronic granulocytic leukaemia (CGL) may terminate as acute lymphoblastic leukaemia, and these lymphocytes have, in some cases, been recognised as pre-B cells. ${ }^{9}$ Furthermore, the $\mathrm{Ph}^{\prime}$ chromosome has been demonstrated in the $\mathrm{B}$ cells of patients with $\mathrm{CGL}^{10}$ whereas there is evidence to suggest that if is absent from $T$ cells." These findings suggest a close relationship between precursors of myeloid cells and B cells. Earlier workers suspected that the hairy cell with its phagocytic properties might belong to the monocytemacrophage line which is more closely related to myeloid cells than B cells are. However, there is now no doubt that $\mathrm{HCL}$ is a tumour of B cells and our cultured spleen cell immunoglobulin synthesis studies serve to confirm this in our patient.

\section{References}

' Manoharan A, Catovsky D, Clein GP, Traub NE, Costello C, O’Brien M, Boralessa H, Galton DAG. Simultaneous or spontaneous occurrence of lympho and myeloproliferative disorders - a report of four cases. Br J Haematol 1981;48:111-6.

2 Taberner DA, Otridge BWE, Chang J. Coexistant chronic lymphocytic leukaemia with polycythemia vera. Postgrad Med J 1977;53:222-3.

${ }^{3}$ Heinle EW, Sarasti HO, Garcia D, Kenny J, Westerman MP. Polycythemia vera associated with lymphomatous disease and myeloma. Arch Intern Med 1966;118:351-5.

${ }^{4}$ Brody JI, Beizer, LH, Schwartz S. Multiple myeloma and myeloproliferative syndromes. Am J Med 1964;36:315-9.

${ }^{5}$ Lawrence JH, Rosenthal RL. Multiple myeloma with polycythemia-report of four cases. Am J Med Sci 1949;218:149-54.

- Stevenson FK, Hamblin TJ, Stevenson GT, Tutt AL. Extracellular idiotypic immunoglobulin arising from human leukaemic B lymphocytes. J Exp Med 1980;152:1484-96.

${ }^{7}$ Hannanm-Harris A, Gordon J, Smith JL. Immunoglobulin synthesis by neoplastic $B$ lymphocytes: free light chain synthesis as a marker of B cell differentiation. J Immunol 1980;125:217781.

${ }^{8}$ Landaw SA. Acute leukemia in polycythemia vera. Semin Hematol 1976;13:33-48.

9 Greaves MF, Verbi W. Reeves BR, Hoffbrand AV, et al. "Pre-B" phenotypes in blast crisis of $\mathrm{Ph}^{\prime}$ positive CML: evidence for a pluripotential stem cell "target". Leukaemia Res 1979;3:18191.

${ }^{10}$ Bernheim A, Berger R, Preud'homme JI, et al. Philadelphia chromosome positive blood B lymphocytes in chronic myelocytic leukaemia. Leukaemia Res 1981;5:331-9.

" Kearney L, Orchard KH, Hibbin J, Goldman JM. T cell cytogenetics in chronic granulocytic leumaekia. Lancet 1982;i:858.

Requests for reprints to: Dr GJ Mufti, Department of Haematology, Royal Victoria Hospital, Bournemouth BHI 4JG, England. 